\title{
The Long-Run Relationship Between Real Exchange Rates and Real Interest Rate Differentials: A Panel Study
}

\author{
RONALD MACDONALD and JUN NAGAYASU*
}

This paper empirically examines the long-run relationship between real exchange rates and real interest rate (RERI) differentials over the recent floating exchange rate period. A panel cointegration estimator is applied to a data set of 14 industrialized countries. In contrast to much other research on the RERI model, we find evidence of statistically significant long-run relationships and plausible point estimates. The failure of most other researchers to establish such relationships may therefore reflect the estimation method used rather than any inherent deficiency in the real exchange rate-real interest rate relationship. [JEL F31]

his paper investigates the long-run relationship between real exchange rates and real interest rate differentials using recently developed panel cointegration methods. Although this kind of relationship has been studied by a number of researchers, ${ }^{1}$ very little evidence in support of the relationship has been reported. For example, Meese and Rogoff (1988) and Edison and Pauls (1993), among others, use the Engle-Granger cointegration method and fail to establish a clear long-run relationship in their analysis. ${ }^{2}$ Somewhat stronger evidence has been

\footnotetext{
"Ronald MacDonald is Professor of International Finance at the University of Strathclyde, and Jun Nagayasu is currently an Economist in the Statistics Department, IMF. This study is based on an earlier paper by MacDonald, Marsh, and Nagayasu (1996). Helpful comments were received from two anonymous referees, Natalie Baumer, Bob Flood, Jaewoo Lee, William Lee, Alfredo M. Leone, Ichiro Otani, Markus Rodlauer, Mark Stone, V. Sundararajan, and Angel Ubide. Helpful advice on panel cointegration tests was provided by Joe Byrne.

${ }^{1}$ See MacDonald (1998) for a survey.

${ }^{2}$ Consistent with these findings, Campbell and Clarida (1987), Huizinga (1987), and Baxter (1994) argue that real exchange rate movements are largely explained by permanent factors which are unrelated to real interest rate differentials.
} 
reported by Edison and Melick (1999) and MacDonald (1997) using the methods of Johansen (1988). This paper provides perhaps the strongest evidence yet in favor of the real exchange rate-real interest rate differential (RERI) model. Our success in establishing clear long-run relationships is attributable to the use of panel cointegration methods.

\section{The Real Exchange Rate-Real Interest Rate Relationship}

The most common way of deriving the RERI relationship, which we refer to as the traditional derivation, is to exploit the Fisher parity condition (1), a real exchange rate identity (2), and the uncovered interest parity condition (UIP) (3): ${ }^{3}$

$$
\begin{aligned}
& \pi_{i t}=r_{i t}+E_{t} \Delta p_{i t+1}, \\
& s_{i t} \equiv p_{i t}-p_{i t}^{*}+q_{i t}, \\
& E_{t} \Delta s_{i t+1}=\pi_{i t}-\pi *_{i t} .
\end{aligned}
$$

For these equations, $s_{i t}$ is the log of the nominal exchange rate (home currency price of a unit of foreign currency) for country $i$ at time $t(i=1, \ldots, N$ and $t=1$, $\ldots, T), q_{i t}$ is the $\log$ of the real exchange rate, $p_{i t}$ is the log of the price level, $\pi_{i t}$ is the nominal interest rate, $r_{i t}$ is the real interest rate, and $E_{t} \Delta p_{i t+1}$ is expected inflation. An asterisk denotes a foreign variable, $\Delta$ is the first difference operator, and $E_{t}\left(\cdot{ }_{i t+1}\right)$ implies the expected value of (.) for time $t+1$, formed at time $t$ using all relevant information. The Fisher parity condition (1) is also assumed to hold in the foreign country. The RERI relationship may then be derived using the expected version of equation (2), $E_{t} s_{i t+1}=E_{t} q_{i t+1}+E_{t} p_{i t+1}-E_{t} p^{*}{ }_{i t+1}$, and combining this with equations (1) and (3):

$$
q_{i t}=E_{t} q_{i t+1}-\left(r_{i t}-r *_{i t}\right) .
$$

This equation says that the current real exchange rate can be explained by the expected future real exchange rate and the real interest rate differential. The latter is assumed to be negatively correlated with the real exchange rate, as in the classic Dornbusch (1976) model. Since the expected real exchange rate is unobservable, it is assumed here to be constant over time and this is consistent with the Dornbusch model. However, we attempt to increase the power of our test over existing studies that exploit this assumption by letting the expected rate vary across individual countries-that is, $E_{t} q_{i t+1}=\alpha_{i}{ }^{4}$ Our econometric analysis is based on the following equation:

\footnotetext{
${ }^{3}$ See Meese and Rogoff (1988) for an alternative way of deriving the real exchange rate-interest rate differential relationship.

${ }^{4}$ Edison and Melick (1999) use a different type of proxy for the expected exchange rate.
} 


$$
q_{i t}=\alpha_{i}+\beta_{i}\left(r_{i t}-r *_{i t}\right)+u_{i t}
$$

where $\alpha_{i}$ captures the fixed effect specific to country $i$, and the residual term is expressed as $u_{i t}$. The term $\beta_{i}$ is the vector of parameters and is written here to allow for a heterogeneous relationship between the real exchange rate and the real interest differential (although in our assessment of the size of $\beta_{i}$, we impose a homogeneity restriction on this parameter). The estimated value of $\beta_{i}$ is expected to be negative, as shown in equation (4). Finally, for operational reasons, we impose a symmetry restriction on the interest rates.

In the context of the above derivation of the RERI, Edison and Melick (1999) have demonstrated that the expected size of $\beta_{i}$ will be positively proportional to the maturity of the bonds underpinning the interest rates. The absolute values of the coefficients on long-term real interest differentials should be greater than those of short-term rate differentials. More specifically, with quarterly data, the estimated value of $\beta_{i}$ should equal $k / 4$, where $k$ is the maturity length. Thus, for the three-month interest rate, we expect the estimated value of $\beta_{i}$ to be $1 / 4$, while for the ten-year maturity rate it should be $40 / 4 .{ }^{5}$ In contrast, however, the size of the constant, $\alpha_{i}$, may be model- and country-specific, since there is no particular economic theory to predict the expected level of real exchange rates. Indeed, in the context of our empirical analysis where we use U.S. real dollar exchange rates per unit of foreign currency, with the base year set arbitrarily to some year by the IMF, the constants must differ arbitrarily.

Unfortunately, the traditional derivation of the RERI model is internally inconsistent with the econometric implementation considered below. This is because the assumption that the expected real exchange rate is constant only makes sense if both absolute and relative purchasing power parity hold each period, which, in turn, implies that ex ante real interest rate parity must hold each and every period. This is clearly an uncomfortable implication of the above framework, although, to our knowledge, all of the papers in this literature share this implication. ${ }^{6}$ An alternative, and perhaps more appealing, derivation of the RERI, which is in fact consistent with the econometric methodology, uses the derivation in Obstfeld and Rogoff (1996, pp. 620-21). This relies on the definition of the real interest rate given in (1), the UIP representation in (3), and equations (6) and (7):

$$
\begin{aligned}
& y_{i t}^{d}=\bar{y}_{i}+\delta_{i}\left(s_{i t}+p_{i t}^{*}-p_{i t}-\bar{q}_{i}\right), \quad \delta_{i}>0, \\
& p_{i t+1}-p_{i t}=\gamma_{i}\left(y_{i t}^{d}-\bar{y}_{i}\right)+s_{i t+1}-s_{i t}+p_{i t+1}^{*}-p_{i t}^{*}, \quad \gamma_{i}>0,
\end{aligned}
$$

\footnotetext{
${ }^{5}$ See Edison and Melick (1999) for a detailed discussion on the expected level of parameters in specification (5).

${ }^{6} \mathrm{We}$ are grateful to an anonymous referee for making this point and suggesting the derivation that follows.
} 
where of variables not previously defined, $y$ denotes real output. Equation (6) is a Dornbusch (1976) aggregate demand equation, in which the deviation of output from the natural rate $\left(\bar{y}_{i}\right)$ is a positive function of the deviation of the current real exchange rate from its equilibrium value. Equation (7) is a standard Phillips curve relationship incorporating foreign inflation developments. The combination of (1), (3), (6), and (7) yields:

$$
q_{i t}=\bar{q}_{i}-\frac{1}{\gamma_{i} \delta_{i}}\left(r_{i t}-r *_{i t}\right),
$$

which indicates that the sensitivity of the current exchange rate with respect to the real exchange rate is determined by $\gamma_{i}$ (i.e., the output gap sensitivity of the price level) and $\delta_{i}$ (the aggregate demand sensitivity to the real exchange rate). This expression is conformable to the econometric specification in equation (5) (where $\beta_{i}=-k /\left(4 \gamma_{i} \delta_{i}\right), k$ is the maturity of the instrument in years, and the long-run real exchange rate equals $\alpha_{i}$ ) as long as there is no $I(1)$ risk premium. ${ }^{7}$ Using this derivation implies that the $\beta_{i}$ coefficient need no longer have a tightly defined relationship with the maturity of the interest rates, as in the traditional derivation discussed above. Rather, the $\beta_{i}$ coefficient here reflects a combination of the maturity effect and the (currency-specific) rate of convergence of the real exchange rate to its long-run equilibrium value. The latter is, in turn, a function primarily of the degree of price stickiness.

Single equation studies, which assume that the expected exchange rate is constant, generally fail to produce statistically significant long-run relationships (see, for example, Meese and Rogoff, 1988; and Edison and Pauls, 1993). Using the cointegration method of Johansen (1988), however, Edison and Melick (1999) and MacDonald (1997) find some evidence of significant long-run relationships for the RERI model. For example, Edison and Melick (1999) use Johansen's method to investigate the RERI for the real bilateral exchange rates of the U.S. dollar against the Canadian dollar, deutsche mark, and yen and the trade weighted value of the U.S. dollar against the Group of Ten currencies. The sample period is 1974 to 1994 (quarterly observations) and two maturity horizons-three months and approximately seven years - are considered. Using a 10 percent significance level, Edison and Melick find that for three of the four exchange rates, there is evidence of a single cointegrating vector in systems containing the long maturity interest rates, while for short horizon maturities there is only a single instance when the null hypothesis of non-cointegration can be rejected. For the systems that produced a single cointegrating relationship, the coefficient values are in conformity with the predictions of the traditional model. ${ }^{8}$

\footnotetext{
${ }^{7}$ Using survey-based expectations, MacDonald (2000) provides some empirical support for the stationarity of various bilateral risk premia.

${ }^{8}$ The RERI model appears to be more successful when the expected real rate is assumed to be timevarying and a function of fundamentals which impart systematic variability into the long-run equilibrium exchange rate (see, for example, MacDonald, 1997).
} 


\section{Description of the Data}

All data are obtained from International Financial Statistics of the International Monetary Fund, and cover the 1976-97 period for 14 industrialized countries: Australia, Austria, Belgium, Canada, Denmark, France, Germany, Italy, Japan, Netherlands, New Zealand, Norway, Switzerland, and the United Kingdom. Detailed definitions of the data used in this paper are given in the Appendix. The exchange rates are bilateral rates against the U.S. dollar, designating the United States as the "foreign country" in our study. The consumer price index (CPI) is the price measure used to calculate inflation, and expected inflation is calculated using a one-sided moving average (MA) filter consisting of four quarterly lags of actual inflation. Exceptions are those of New Zealand and the United States where MA(3) and MA(2) filters are used, respectively. ${ }^{9}$ Both long- and short-term nominal interest rates are used to construct the real interest rates through equation (1). ${ }^{10}$

Our data set requires a cautionary note. In a cross-country study such as ours, there is inevitably a trade-off between data availability and data comparability. In order to maximize the power of the panel cointegration tests, we have opted for the widest group of currencies. This inevitably means that our data are not exactly comparable across countries. The comparability of price series in panel studies is well known. (See, for example, Frankel and Rose, 1996.) In our study, however, this is compounded by country comparability issues relating to the interest rates. Although our short-term interest rates are reasonably comparable across countries (the majority being money market rates), this is not the case for our long-term rates, which vary in maturity from three to ten years. To obtain consistent maturity yields across countries would greatly reduce the cross-sectional dimensions of our data set and we have not adopted that strategy here. But we are encouraged by the study of Flood and Taylor (1996), who use a heterogeneous set of medium term interest rates to test the UIP hypothesis in a panel setting and are unable to reject the hypothesis.

We analyze orders of integration of the data using the Augmented Dickey-Fuller (ADF) test, a standard unit root test. The ADF statistics are calculated with a constant and a constant plus a time trend, respectively. These tests have a null hypothesis of non-stationarity against an alternative of stationarity (around a constant or a constant and trend). In all of these tests, we started with a lag length of five, and sequentially deleted insignificant lags until the last lag was significant. The results are reported in Table 1 for both levels and differences of the series and indicate that the majority of real exchange rates are clearly $I(1)$ processes. The results with respect to the real interest rates are ambiguous in the sense that some interest rate differentials appear to be stationary, thereby implying that there is no long-run relationship of the form (5). In conducting the panel cointegration tests, we therefore present panel estimates based on the full panel, as

\footnotetext{
${ }^{9}$ The New Zealand system fails to converge with four lags and similarly the U.S. system with three or four lags does not converge.

${ }^{10} \mathrm{We}$ also considered a different approximation of inflation (e.g., the ex post inflation); however, the overall results remain unchanged.
} 


\section{Table 1. Unit Root Testa}

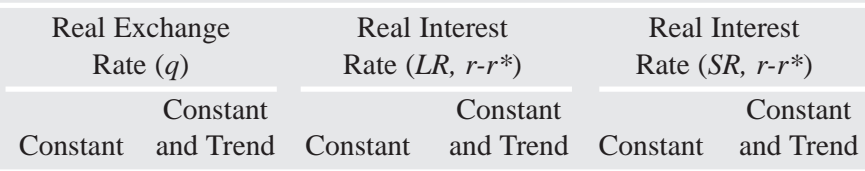

(A) Level

$\begin{array}{lllllll}\text { Australia } & -1.698 & -1.781 & -1.794 & -1.674 & -2.376 & -2.312 \\ \text { Austria } & -1.707 & -1.912 & -2.591 & -2.823 & -2.805 & -3.045 \\ \text { Belgium } & -1.796 & -1.796 & -2.998^{b} & -2.993 & -2.705 & -2.723 \\ \text { Canada } & -1.576 & -1.876 & -1.512 & -3.420 & -2.064 & -1.957 \\ \text { Denmark } & -2.073 & -2.159 & -1.550 & -4.612^{c} & -4.144^{c} & -4.168 c \\ \text { France } & -1.892 & -1.906 & -5.192^{c} & -5.150^{c} & -2.611 & -2.585 \\ \text { Germany } & -1.790 & -1.861 & -1.992 & -2.652 & -2.295 & -2.803 \\ \text { Italy } & -1.936 & -1.963 & -3.053^{b} & -3.047 & -2.600 & -2.913 \\ \text { Japan } & -1.671 & -2.025 & -2.526 & -2.523 & -3.229^{b} & -3.206 \\ \text { Netherlands } & -1.941 & -1.939 & -1.739 & -2.177 & -1.585 & -1.408 \\ \text { New Zealand } & -1.872 & -2.029 & -2.974^{b} & -2.931 & -2.781 & -2.837 \\ \text { Norway } & -2.052 & -2.087 & -1.893 & -1.782 & -2.948^{b} & -2.937 \\ \text { Switzerland } & -2.040 & -2.189 & -1.572 & -2.868 & -1.884 & -2.550 \\ \text { United Kingdom } & -2.285 & -2.273 & -2.359 & -2.297 & -4.202^{c} & -4.057 b\end{array}$

\section{(B) Difference}

$\begin{array}{lcccccc}\text { Australia } & -7.861^{c} & -7.808^{c} & -10.36^{c} & -10.33^{c} & -10.68^{c} & -10.64^{c} \\ \text { Austria } & -6.554^{c} & -6.514^{c} & -4.051^{c} & -15.80^{c} & -11.58^{c} & -11.52^{c} \\ \text { Belgium } & -6.362^{c} & -6.340^{c} & -9.818^{c} & -9.754^{c} & -8.734^{c} & -8.699^{c} \\ \text { Canada } & -2.997^{b} & -2.960 & -7.639^{c} & -7.656^{c} & -11.30^{c} & -11.32^{c} \\ \text { Denmark } & -6.750^{c} & -6.710^{c} & -9.913^{c} & -9.830^{c} & -12.63^{c} & -12.55^{c} \\ \text { France } & -6.433^{c} & -6.391^{c} & -13.33^{c} & -13.23^{c} & -10.46^{c} & -10.41^{c} \\ \text { Germany } & -6.551^{c} & -6.514^{c} & -4.454^{c} & -4.452^{c} & -2.975^{b} & -2.955 \\ \text { Italy } & -6.747^{c} & -6.712^{c} & -11.31^{c} & -11.23^{c} & -10.43^{c} & -10.37 c \\ \text { Japan } & -6.645^{c} & -6.616^{c} & -12.62^{c} & -12.55^{c} & -8.311^{c} & -8.260^{c} \\ \text { Netherlands } & -6.566^{c} & -6.532^{c} & -9.800^{c} & -9.799^{c} & -9.932^{c} & -9.924^{c} \\ \text { New Zealand } & -2.470 & -2.441 & -11.51^{c} & -11.45^{c} & -8.591^{c} & -8.537^{c} \\ \text { Norway } & -7.167^{c} & -7.125^{c} & -12.17^{c} & -12.15^{c} & -11.59^{c} & -11.52^{c} \\ \text { Switzerland } & -6.667^{c} & -6.623^{c} & -13.90^{c} & -4.177^{c} & -11.47^{c} & -11.39^{c} \\ \text { United Kingdom } & -7.444^{c} & -7.399^{c} & -5.823^{c} & -5.805^{c} & -6.587^{c} & -6.780^{c}\end{array}$

${ }^{a}$ The Augmented Dickey-Fuller test is implemented to test the null hypothesis that the series in question is $I(1)$ in the columns under "Level" or $I(2)$ in the columns under "Difference." The critical values are obtained from MacKinnon (1991). The full sample is used for calculations.

${ }^{b}$ Statistics that are significant at the 5 percent level.

${ }^{c}$ Statistics that are significant at the 1 percent level. 
well as panels in which the stationary real interest rate differentials have been excluded. For long- and short-term yields, this reduces the number of countries included to eight (Australia, Austria, Germany, Japan, Netherlands, Norway, Switzerland, and the United Kingdom) and seven (Australia, Austria, Belgium, France, Italy, Netherlands, and Switzerland), respectively.

\section{Empirical Results}

The existence of long-run relationships is examined using two types of cointegration tests. The individual country cointegration analysis is conducted using the multivariate cointegration test developed by Johansen (1988). This technique is applied to countries whose exchange rates and interest rate differentials were established as being I(1) series. The null hypothesis of the Johansen test is that of non-cointegration against the alternative of cointegration. We estimate both Johansen Max and Trace statistics for each model. Since these tests are now well known, we do not elaborate on them here.

For the panel cointegration tests, we exploit the methods of Pedroni (1997a), who has derived a number of test statistics and their asymptotic distributions, which can be used in a heterogeneous panel setting. Since these tests have a number of useful features compared with other integration/cointegration tests, Pedroni's techniques have been applied to several areas in economics. ${ }^{11}$ For instance, the panel cointegration test is more flexible than the panel unit root test (e.g., Quah, 1994; Im and others, 1997) in that it does not require a priori restrictions on the parameters of the model. In addition, unlike the standard Johansen test, it does not have the problem of identifying unique cointegrating relationships.

One test proposed by Pedroni is the analogue to the Augmented Dickey-Fuller $(\mathrm{ADF})$ test statistic and is based on the following specification:

$$
\Delta \hat{u}_{i t}=\left(\rho_{i}-1\right) \hat{u}_{i t-1}+\sum_{j=1}^{p_{i}} \theta_{i j} \Delta \hat{u}_{i t-j}+\zeta_{i t}
$$

where the $\hat{u}_{i t}$ are estimates of the residuals obtained from equation (5), and the lag, $p_{i}$, ensures that $\zeta_{i t}$ is a random error. The null hypothesis of this test is that of noncointegration, against the alternative of cointegration, and is tested by imposing a parameter restriction $\left(\rho_{i}=1\right)$. Pedroni proposes the following adjusted $t$-statistic to evaluate this hypothesis.

$$
A D F t=\left(\hat{s}^{2} \sum_{i=1}^{N} \sum_{t=1}^{T} L_{11 i}^{-2} \hat{u}_{i t-1}^{2}\right)^{-1 / 2} \sum_{i=1}^{N} \sum_{t=1}^{T} L_{11 i}^{-2}\left(\hat{u}_{i t-1} \Delta \hat{u}_{i t}\right),
$$

where $L_{i}$ is the lower triangular component of $\Omega_{i}$, and $\Omega_{i}$ is positive definite $\left(\left(I_{N} \otimes \Omega_{i}\right)>0\right)$ being the long-run covariance matrix for the residuals of the

\footnotetext{
${ }^{11}$ See, for instance, Canzoneri, Cumby and Diba (1996), Chinn (1996), Pedroni (1997b), and Nagayasu (1998).
} 
system of exchange rates and interest rate differentials. ${ }^{12}$ The term, $\hat{s}^{2}$, is the long-run variance $\left(\hat{s}^{2}=(1 / N) \sum_{i=1}^{N} L_{11 i}^{-2} \hat{s}_{i}^{2}\right)$, where the $\hat{s}_{i}^{2}$ are standard contemporaneous variances of the residuals $\left(\zeta_{i}\right)$, obtained from equation(9).

The finite sample distributions from the Monte Carlo simulations are tabulated in Pedroni (1997a), and the constructed $t$ statistics need to be smaller than the critical values to reject the null hypothesis of non-cointegration. Pedroni (1997a) demonstrates that this statistic is normally distributed with adjustments in the mean and variance and also shows that the size distortion of this test is small with large observations $(T)$, as long as the moving average coefficients in the assumed data generating process for the errors, are positive. Pedroni's simulations also indicate that the test has good power properties.

Finally, the panel estimates of $\beta$, which impose homogenous parameter restrictions on $\beta_{i}$ across all individuals, and the corresponding standard errors, are calculated using the panel fully modified ordinary least squares (FMOLS) estimator of Pedroni (1996). These estimates are obtained under the condition that two variables, say, $x_{i t}$ and $y_{i t}$, are $I(1)$ and are cointegrated, and the autocorrelation adjustment is made by a non-parametric method. In the heterogeneous panel context, these estimates are found to be asymptotically unbiased and independent of nuisance parameters under the null hypothesis and, furthermore, the corresponding statistic has a normal distribution. ${ }^{13}$

The results from our cointegration analysis are summarized in Table 2, where both the Johansen and Pedroni tests examine the null hypothesis of noncointegration against the alternative of cointegration. The single country results, based on the Johansen method (reported in part A of Table 2), confirm the findings of most previous studies: with a constant equilibrium exchange rate there is a very weak long-run relationship between real exchange rates and real interest rate differentials on the basis of the individual country results. ${ }^{14}$ Thus only for the Swiss franc real exchange rate relationship can the null hypothesis of noncointegration be rejected at the 5 percent significance level.

In contrast to the single country results, our panel estimates, reported in part B of Table 2, provide clear empirical evidence for the existence of a statistically significant long-run RERI relationship, especially when long-term interest rates are used. For the full panel of countries, the estimated value of the panel ADF $t$ statistic provides a clear rejection of the null hypothesis at the 1 percent level or better. Adjusting these statistics for the mean and variance, as suggested by Pedroni (1997a), still produces a clear rejection of the null hypothesis (at the 1 percent level) in the equations featuring long rates, but not in the equations featuring short rates. As we mentioned previously, the full panel

\footnotetext{
${ }^{12}$ Conceptually, $\Omega_{i}=\bar{\Omega}_{i}+\Pi_{i}+\Pi_{i}^{\prime}$, where $\bar{\Omega}_{i}=E\left(u_{1} u_{1}^{\prime}\right)$ and $\Pi_{i}=\sum_{z=2}^{\infty} E\left[u_{1} u_{z}^{\prime}\right]$, and for operational purposes, the Newey-West technique is applied to guarantee non-negative estimates for finite sample sizes.

${ }^{13}$ Therefore, the testable specification for the bivariate case ( $x$ and $\left.y\right)$ can be expressed as follows: $y_{i t}=\alpha_{1 i}+\beta x_{i t}+v_{i t}$ and $x_{i t}=\alpha_{2 i}+\beta x_{i t-1}+\phi_{i t}$. This is analogous to the standard single equation FMOLS estimator, only now we allow for the $i$ dimension. As in the standard case, the panel residuals $\left(v_{i t}\right.$ and $\left.\phi_{i t}\right)$ should be stationary series.

${ }^{14}$ The lag length in all of the VAR systems was set equal to five, which satisfied the requirement of random errors.
} 


\title{
Table 2. Cointegration Results
}

\author{
Exchange Rates and \\ Long-Run Interest Rates
}

Exchange Rates and

Short-Run Interest Rates

\section{(A) Single Country Johansen Tests ${ }^{a}$}

\begin{tabular}{lccccccccc} 
& \multicolumn{2}{c}{ Null (max) } & \multicolumn{2}{c}{ Null (Trace) } & \multicolumn{2}{c}{ Null (max) } & \multicolumn{2}{c}{ Null (Trace) } \\
Countries & $\mathrm{r}==0$ & $\mathrm{r}<=1$ & $\mathrm{r}==0$ & $\mathrm{r}<=1$ & $\mathrm{r}==0$ & $\mathrm{r}<=1$ & $\mathrm{r}==0$ & $\mathrm{r}<=1$ \\
Australia & 7.893 & 4.616 & 12.51 & 4.616 & 6.526 & 3.926 & 10.45 & 3.926 \\
Austria & 8.201 & 4.174 & 12.37 & 4.174 & 10.06 & 3.022 & 13.08 & 3.022 \\
Belgium & - & - & - & - & 7.738 & 4.587 & 12.32 & 4.587 \\
Canada & - & - & - & - & - & - & - & - \\
Denmark & - & - & - & - & - & - & - & - \\
France & - & - & - & - & 5.278 & 4.027 & 9.305 & 4.027 \\
Germany & 7.383 & 5.408 & 12.79 & 5.408 & - & - & - & - \\
Italy & - & - & - & - & 7.578 & 4.750 & 12.33 & 4.750 \\
Japan & 9.404 & 3.177 & 12.58 & 3.177 & - & - & - & - \\
Netherlands & 6.726 & 6.319 & 13.04 & 6.319 & 6.789 & 4.394 & 11.18 & 4.394 \\
New Zealand & - & - & - & - & - & - & - & - \\
Norway & 11.33 & 4.242 & 15.57 & 4.242 & - & - & - & - \\
Switzerland & $16.08^{b}$ & 3.210 & 19.29 & 3.210 & 12.49 & 3.083 & 15.57 & 3.083 \\
United Kingdom & 11.75 & 6.776 & 18.53 & 6.776 & - & - & - & - \\
& & & & & & & &
\end{tabular}

(B) Panel Tests ${ }^{d}$

\begin{tabular}{lcccc} 
& $\mathrm{N}=14$ & $\mathrm{~N}=8$ & $\mathrm{~N}=14$ & $\mathrm{~N}=7$ \\
\hline ADF t-value & -8.962 & -7.733 & -7.629 & -4.731 \\
ADF adj. t-value- & $-2.581^{c}$ & $-2.945^{c}$ & -1.199 & -0.160 \\
FOMOLS $\beta$ estimate & $-3.639^{2}$ & -3.747 & -0.834 & -0.609 \\
FOMOLS adj. t-value $\mathrm{H}_{0}: \beta=0.0$ & $-7.375^{c}$ & $-7.336^{c}$ & $-2.285^{b}$ & -0.918 \\
FOMOLS adj. t-value $\mathrm{H}_{0}: \beta=10.0$ & $12.91^{c}$ & $9.694^{c}$ & - & - \\
FOMOLS adj. t-value $\mathrm{H}_{0}: \beta=0.25$ & - & - & -1.538 & -0.444 \\
ADF t-value with a time dummy & -11.84 & -10.39 & -14.32 & -9.880 \\
ADF adj. t-value with a time dummy & $-5.565^{c}$ & $-5.700^{c}$ & $-8.137^{c}$ & $-5.499 c$
\end{tabular}

${ }^{a} \mathrm{~A}$ constant term enters the long-run specification, and the Trace and Max statistics are adjusted using the sample correction of Reimers (1992). The critical values for the Johansen test are obtained from Ostwerwald-Lenum (1992). The critical values for Pedroni's ADF test are based on the standard normal distribution. Adjusted statistics (denoted "adj.") are obtained by correcting the mean and variance as suggested by Pedroni (1997a). The significance of the statistics in part (B) is indicated for only the adjusted values.

${ }^{b}$ Denotes significance at the 5 percent level.

${ }^{c}$ Denotes significance at the 1 percent level.

${ }^{d}$ The sample with $\mathrm{N}=14$ comprises the whole set of countries, while $\mathrm{N}=8$ includes Australia, Austria, Germany, Japan, the Netherlands, Norway, Switzerland, and the United Kingdom, and $\mathrm{N}=7$ includes Australia, Austria, Belgium, France, Italy, the Netherlands, and Switzerland. 
contains some country pairings that appear to have stationary real interest differentials and it is possible that they create a bias toward rejection of the null. The panel cointegration tests are therefore also implemented on the panels comprising only non-stationary combinations of real exchange rates and real interest rates, as discussed above. The sub-panel containing long rates also produces a convincing rejection of the null of non-cointegration, although the sub-panel with short rates does not. The relatively stronger empirical support for the model when long-term interest rates are used is perhaps consistent with the fact that the maturity of long-term interest rates more closely corresponds to the persistence observed in real exchange rates.

All of the country pairings in our panels have the United States as the numerator currency. Of course, since both exchange rates and interest rates are likely to be heavily influenced by developments in the United States, the variables used in this study may not be independent across countries. We therefore also consider an alternative specification of (5) which contains common time dummies $\left(\tau_{t}\right)$. These results are also reported in Table 2 and give even stronger support for the RERI relationship, since the absolute value of all of the ADF statistics rises and the RERI model is now valid even in the reduced panel with short-term rates.

Further confirmation of our model specification comes from the estimated values of $\beta$. Given our comments about the heterogeneity of the long-term interest rates used in this study, it is important to make some assumption about how these rates are related before making inferences based on point estimates. Our particular assumption is that the long rates used in this study move closely together through a term structure relationship. Both derivations of the RERI model predict that $\beta$ should be significantly negative and this is indeed what we find in the majority of cases. Furthermore, there would appear to be a clear term structure relationship since the absolute magnitude of the beta coefficient rises as the maturity of the bonds increases. Numerically, the point estimates on short rates are close to the levels expected in the traditional derivation of the RERI model. In fact, both are statistically indistinguishable from -0.25. Although both long rate coefficients are below -1.0 , they are statistically different from the value predicted in the traditional derivation of the RERI model (of minus 10). Perhaps this reflects the greater importance of price stickiness, as in the Obstfeld and Rogoff (1996) derivation of the RERI, for the longer term yields.

\section{Conclusion}

In this paper we have empirically analyzed the long-run relationship between real exchange rates and real interest rate differentials, using a panel data set for 14 industrialized countries during the recent floating exchange rate period. Our empirical results using Johansen's method provide evidence consistent with previous single country studies, since the RERI only produces a statistically significant long-run relationship for one currency pairing. However, the use of a panel cointegration test produced a clear rejection of the null hypothesis of 
non-cointegration, even when the equilibrium real exchange rate is assumed constant. The rejection of the null hypothesis is clearest when long-term interest rates are used. Furthermore, the estimated slope coefficients are in conformity with the model specification. Our results, therefore, would seem to provide further evidence that important fundamentals-based exchange rate relationships may be in the data after all, and the failure of others to establish such relationships may reflect the estimation method used rather than any inherent deficiency of the fundamentals-based models.

\section{APPENDIX}

\section{Table A1. Definition of Variables a}

\begin{tabular}{|c|c|c|c|c|c|c|}
\hline \multicolumn{2}{|c|}{$\begin{array}{l}\text { Exchange Rate } \\
\text { (Period average) }\end{array}$} & \multirow{2}{*}{$\begin{array}{c}\text { Price } \\
\text { (CPI) } \\
64\end{array}$} & \multicolumn{2}{|l|}{ SR Interest Rate } & \multicolumn{2}{|l|}{ LR Interest Rate } \\
\hline Australia & $\mathrm{rf}$ & & Treasury bill rate & $(60 c)$ & Govt bond yield & (61) \\
\hline Austria & $\mathrm{rf}$ & 64 & Money market rate & $(60 b)$ & Govt bond yield & (61) \\
\hline Belgium & $\mathrm{rf}$ & 64 & Money market rate & $(60 b)$ & Govt bond yield & (61) \\
\hline Canada & $\mathrm{rf}$ & 64 & Money market rate & $(60 b)$ & Govt bond yield & (61) \\
\hline Denmark & $\mathrm{rf}$ & 64 & Money market rate & $(60 b)$ & Govt bond yield & (61) \\
\hline France & $\mathrm{rf}$ & 64 & Money market rate & $(60 b)$ & Govt bond yield & (61) \\
\hline Germany & $\mathrm{rf}$ & 64 & Money market rate & $(60 b)$ & Govt bond yield & (61) \\
\hline Italy & $\mathrm{rf}$ & 64 & Money market rate & $(60 b)$ & Govt bond yield & (61) \\
\hline Japan & $\mathrm{rf}$ & 64 & Money market rate & $(60 b)$ & Govt bond yield & (61) \\
\hline Netherlands & $\mathrm{rf}$ & 64 & Money market rate & $(60 b)$ & Govt bond yield & (61) \\
\hline New Zealand & $\mathrm{rf}$ & 64 & Discount rate & $(60)$ & Govt bond yield & (61) \\
\hline Norway & $\mathrm{rf}$ & 64 & Money market rate & $(60 b)$ & Govt bond yield & (61) \\
\hline Switzerland & $\mathrm{rf}$ & 64 & Discount rate & $(60)$ & Govt bond yield & (61) \\
\hline United Kingdom & $\mathrm{rf}$ & 64 & Money market rate & $(60 b)$ & Govt bond yield & (61) \\
\hline United States & - & 64 & Treasury bill rate & $(60 c)$ & Govt bond yield & (61) \\
\hline
\end{tabular}

${ }^{a}$ The numbers in parentheses indicate the code numbers of the variables which are consistent with the IMF classification.

\section{REFERENCES}

Baxter, Marianne, 1994, "Real Exchange Rates and Real Interest Differentials: Have We Missed the Business-Cycle Relationship?" Journal of Monetary Economics, Vol. 33 pp. 5-37.

Campbell, John Y., and Richard H. Clarida, 1987, "The Dollar and Real Interest Rates," Carnegie-Rochester Conference Series on Public Policy, Vol. 27 (Autumn), pp. 103-40.

Canzoneri, Matthew B., Robert E. Cumby, and Behyad Diba, 1996, "Relative Labor Productivity and the Real Exchange Rates in the Long Run: Evidence for a Panel of OECD Countries," NBER Working Paper No. 5676 (Cambridge, Massachusetts: National Bureau of Economic Research).

Chinn, Menzie D., 1996, "Sectoral Productivity, Government Spending and Real Exchange Rates: Empirical Evidence for OECD Countries," Working Paper (Santa Cruz, California: Economics Department, University of California). 
Dornbusch, Rudiger, 1976, “Expectations and Exchange Rate Dynamics," Journal of Political Economy, Vol. 84 (December), pp. 1161-76.

Edison, Hali J., and William R. Melick, 1999, "Alternative Approaches to Real Exchange Rates and Real Interest Rates: Three Up and Three Down," International Journal of Finance and Economics, Vol. 4 (April), pp. 93-112.

Edison, Hali J., and B. Dianne Pauls, 1993, "A Re-Assessment of the Relationship between Real Exchange Rates and Real Interest Rates: 1974-1990," Journal of Monetary Economics, Vol. 31(April), pp. 165-87.

Flood, Robert P., and Mark P. Taylor, 1996, "Exchange Rate Economics: What's Wrong with the Conventional Macro Approach?" The Microstructure of Foreign Exchange Markets, eds. J.A. Frankel and others (Chicago: The University of Chicago Press).

Frankel, Jeffrey A., and Andrew K. Rose, 1996, "A Panel Project on Purchasing Power Parity: Mean Reversion within and between Countries," Journal of International Economics, Vol. 40 (February), pp. 209-24.

Huizinga, John, 1987, "An Empirical Investigation of the Long Run Behavior of Real Exchange Rates," Carnegie-Rochester Conference Series on Public Policy, Vol. 27 (Autumn), pp. 149-214.

Im, Kyung S., M. Hashem Pesaran, and Yongcheol Shin, 1997, "Testing for Unit Roots in Heterogeneous Panels," Working Paper (Cambridge: Department of Applied Economics, Cambridge University).

Johansen, Soren, 1988, "Statistical Analysis of Co-integration Vectors," Journal of Economic Dynamics and Control, Vol. 12 (June-September), pp. 231-54.

MacDonald, Ronald, 1997, "What Determines Real Exchange Rates: The Long and Short of It," IMF Working Paper 97/21 (Washington: International Monetary Fund).

MacDonald, Ronald, 1998, "What Do We Really Know about Real Exchange Rates?" Oesterreichische Nationalbank Discussion Paper, No. 28.

MacDonald, Ronald, 2000, "Is the Foreign Exchange Market 'Risky'? Some New SurveyBased Results," Journal of Multinational Financial Management, forthcoming.

MacDonald, Ronald, Ian W. Marsh, and Jun Nagayasu, 1996, "Revisiting the Long-Run Relationship Between Real Exchange Rates and Real Interest Rate Differentials," ICMM Discussion Paper Series, No. 39 (Glasgow: Economics Department, University of Strathclyde).

MacKinnon, James G., 1991, "Critical Values for Cointegration Tests," Long-run Economic Relationships: Readings in Cointegration, ed. by R. F. Engle and C. W. J. Granger (Oxford: Oxford University Press).

Meese, Richard, and Kenneth Rogoff, 1988, "What Is Real? The Exchange Rate-Interest Differential Relation Over the Modern Floating-Rate Period," Journal of Finance, Vol. XLIII, No. 4 (September), pp. 933-48.

Nagayasu, Jun, 1998, "Does the Long-Run PPP Hypothesis Hold for Africa?: Evidence from Panel Cointegration Study," IMF Working Paper 98/123 (Washington: International Monetary Fund).

Obstfeld, Maurice, and Kenneth Rogoff, 1996, Foundations of International Economics (Cambridge: The MIT Press).

Osterwald-Lenum, Michael, 1992, "A Note with Quantiles of the Asymptotic Distribution of the Maximum Likelihood Cointegration Rank Test Statistics," Oxford Bulletin of Economics and Statistics, Vol. 54 (August), pp. 461-71. 
Pedroni, Peter L., 1996, "Fully Modified OLS for Heterogeneous Cointegrated Panels and the Case of Purchasing Power Parity," Working Paper 96-020, (Bloomington, Indiana: Economics Department, Indiana University).

Pedroni, Peter L., 1997a, "Panel Cointegration: Asymptotic and Finite Sample Properties of Pooled Time Series Tests with An Application to the PPP Hypothesis," Working Paper (Bloomington, Indiana: Economics Department, Indiana University).

Pedroni, Peter L., 1997b, "On the Role of Human Capital in Growth Models: Evidence from a Nonstationary Panel of Developing Countries," Working Paper (Bloomington, Indiana: Economics Department, Indiana University).

Quah, Danny, 1994, "Exploiting Cross-Section Variance for Unit Root Inference in Dynamic Data," Economics Letters, Vol. 44 (Nos. 1-2), pp. 9-19.

Reimers, Hans-Eggert, 1992, “Comparisons of Tests for Multivariate Cointegration," Statistical Papers, Vol. 33, pp. 335-59. 